\title{
Synthesis and biological studies of $\mathrm{Co}(\mathrm{II})$ and $\mathrm{Cd}(\mathrm{II}) \mathbf{5 - ( 3 , 4 , 5 -}$ trimethoxybenzyl) pyrimidine-2,4-diamine (Trimethoprim) complexes
}

\author{
Adedibu C. TELLA* and Joshua A. OBALEYE \\ Department of Chemistry, P.M.B. 1515, University of Ilorin, Nigeria. \\ *Corresponding author,E-mail: adedibu@unilorin.edu.ng,jobaleye@yahoo.com
}

\begin{abstract}
Two metal complexes of $\mathrm{Co}(\mathrm{II})$ and $\mathrm{Cd}(\mathrm{II})$ 5-(3,4,5-trimethoxybenzyl) pyrimidine-2,4-diamine (Trimethoprim) were synthesized and characterized by both analytical and spectroscopic methods. They are 4coordinate complex containing two molecules of 5-(3,4,5-trimethoxybenzyl) pyrimidine-2,4-diamine (TMP) and two chloride ions. A distorted tetrahedral geometry is suggested for their structure, where TMP behaves as a monodentate ligand. The metal binds through the pyrimidine $\mathrm{N}(1)$ of the ligand. The complexes have been screened for antiplasmodial activity against Plasmodium berghei and the results show that they are less active than the parent ligand. Toxicological study was carried out by investigating the effect of administration of the complexes on alkaline phosphatase activity of kidney, liver and serum of albino rats and they are found to be nontoxic.

(C) 2010 International Formulae Group. All rights reserved.
\end{abstract}

Keywords: Trimethoprim, Alkaline phosphatase activity, Monodentate.

\section{INTRODUCTION}

The emergence of drug resistance as a worldwide problem in several diseases, specifically in cancer and tropically diseases make it mandatory for scientists to broaden the domain of available therapies and bioinorganic complexes provide diversity and unique scaffolds for potential exploitation of therapeutic effect (Orvig and Abrahams, 1999). Many drugs possess modified toxicological and pharmacological properties when in form of metal complexes (Anacona and Gil, 2005)

In the 1980s and 1990s, interest in coordination complexes of known chemotherapeutic agents began to emerge. It was not long before coordination complexes of chloroquine were synthesized and evaluated for efficacy against both chloroquine-sensitive and chloroquineresistant strains of Plasmodium falciparum (Navarro et al., 1997; Biot et al., 1999). It is not surprising that antiplasmodial efficacy proved to be somewhat dependent on both metal and ligand (Sorenson, 1976; SanchezDelgado et al., 1993). Trimethoprim is a bacteriostatic antibiotic mainly used in the prophylaxis and treatment of urinary tract infection. It belongs to chemotherapeutic class of drug known as dihydrofolate reductase inhibitor (Rang et al., 1999). Cotrimoxazole (trimethoprim combined with sulphamethoxazole) is used in urinary tract infections (E. coli) respiratory infections (Haemophilies 
influenzae and pneumococci) and and pneumocystis (Neal, 1993). As a continuation of our work (Obaleye et al., 2007; Obaleye et al., 2008; Obaleye et al., 2009; Tella and Obaleye, 2009; Tella and Obaleye, 2010a, 2010b) on metal interactions with chemotherapeutic agents, we investigate the coordination chemistry of 5-(3,4,5trimethoxybenzyl) pyrimidine-2,4-diamine (Trimethoprim) with $\mathrm{Co}(\mathrm{II})$ and $\mathrm{Cd}(\mathrm{II})$ metals in an attempt to examine the modes of binding in the solid state and to study biological activity.

\section{MATERIALS AND METHODS}

5-(3,4,5-trimethoxybenzyl) pyrimidine -2,4-diamine (Trimethoprim) was purchased from Sigma Chemical Co, (USA). All solvents and other reagents were of high purity (Aldrich and Sigma) and were used without further purification. $\mathrm{CdBr}_{2} \cdot 4 \mathrm{H}_{2} \mathrm{O}$ and $\mathrm{CoCl}_{2} \cdot 6 \mathrm{H}_{2} \mathrm{O}$ were used as metal ion sources.

IR spectra of the samples in $\mathrm{KBr}$ pellets were obtained in the ranges of 4000-400 $\mathrm{cm}^{-1}$ using FTIR spectrometer. Metal Analyses were determined by atomic absorption spectroscopy with Perkin-Elmer Spectrometer, model 3110. The analyses of carbon, hydrogen and nitrogen were carried out on a Perkin-Elmer 204C microanalyzer. Mass spectra recorded on a Micromass platform spectrometer instrument using DMSO as solvent. UV-Vis spectra were obtained on Aquamate v4.60 spectrophotometer. Magnet susceptibility measurement of the complexes were determined at room temperature by the Gouy balance with mercury tetrathiocynatocobaltate(II) $\left\{\mathrm{Hg}\left[\mathrm{Co}(\mathrm{NCS})_{4}\right]\right\} \quad$ used as calibrant.

\section{Synthesis of the complexes}

The method described by Tella (2008) was used for the synthesis of the complexes.

\section{Synthesis of $\mathrm{Co}(\mathrm{TMP}) \mathrm{Cl}_{2}$}

To a stirred solution of 5-(3,4,5trimethoxybenzyl) pyrimidine-2,4-diamine $(0.580 \mathrm{~g}, 2 \mathrm{mmol})$ in methanol $(40 \mathrm{ml})$ was added a solution of $\mathrm{CoCl}_{2}$. $6 \mathrm{H}_{2} \mathrm{O}(0.237 \mathrm{~g}, 1$ mmol) in methanol $(40 \mathrm{ml})$. The resulting solution was refluxed for 2 hours at $80{ }^{\circ} \mathrm{C}$ and allowed to evaporate slowly for three weeks at room temperature. Blue crystals obtained were filtered and dried in a vacuum.

Yield: $60 \%$, M.wt $=719.57$, M.pt $=$ $268{ }^{\circ} \mathrm{C}$, Anal. Calcd. for $\mathrm{C}_{28} \mathrm{H}_{36} \mathrm{~N}_{8} \mathrm{O}_{6} \mathrm{Cl}_{2} \mathrm{Co}$; C, 47.28; H, 5.07; N, 15.76, Co, 8.29 Found: C, 47.45; H, 4.95; N, 15.92; Co, 8.27.IR (KBr, $\left.\mathrm{cm}^{-1}\right): 3465,3336,3184,2936,1664,1634$, $1590,1473,1243,1129,995,784,620,480$ UV-vis (methanol) $\lambda$, nm: 410, 455, 601 .

\section{Synthesis of $\mathrm{Cd}(\mathrm{TMP})_{2} \mathrm{Br}_{2}$}

A solution of 5-(3,4,5-trimethoxybenzyl) pyrimidine-2,4-diamine $(0.580 \mathrm{~g}, 2$ $\mathrm{mmol})$ in hot methanol $(30 \mathrm{ml})$ was added slowly to a solution of the $\mathrm{CdBr}_{2} \cdot 4 \mathrm{H}_{2} \mathrm{O}$ $(0.344 \mathrm{~g}, 1 \mathrm{mmol})$ in methanol $(25 \mathrm{ml})$. The resulting turbid solution gave deposition of crystals after 3 hours at the bottom of flask, crystals were removed by decantation. Recrystallization of the crystals from methanol gave white crystals which were filtered and dried in a vacuum.

Yield: $80 \%$, M.wt $=852.84, \mathrm{M} \cdot \mathrm{pt}=235$ ${ }^{\circ} \mathrm{C}$, Anal. Calcd. for $\mathrm{C}_{28} \mathrm{H}_{36} \mathrm{~N}_{8} \mathrm{O}_{6} \mathrm{Br}_{2} \mathrm{Cd}$ : C; 39.40; H,4.22, N, 13.15; Cd, 13.10: Found C, 39.51; H, 4.15; N, 13.21; Cd, 13.05. IR (KBr, $\mathrm{cm}^{-1}$ ): 3429, 3341, 3227, 3003, 2938, 2833, 1631, 1590, 1333, 1244, 1125, 1000, 778, $683,585,529,457$. UV-Vis (DMSO) $\lambda$, nm: $275 \mathrm{~nm} .{ }^{1} \mathrm{HNMR}$ (DMSO-d $)_{6}$ ): $\delta 6.90 \mathrm{H}(6)$; $6.5 \mathrm{H}(7) ; 7.5 \mathrm{H}\left(6^{\prime}\right) / \mathrm{H}\left(2^{\prime}\right)$.

\section{Antiparasitic screening}

Plasmodium berghei and mice were collected from Institute of Advanced Medical Research and Training, University of Ibadan, Ibadan, Nigeria. Mice for the experiment were infected as described by previous workers (Sanchez - delgado et al., 1996 ; Sayles and Wassom, 1988). Twenty five Swiss mice (male) were divided into groups of five animals each and kept in cages fed with mice cubes and water ad libitum.

Group 1: Control

Group 2: Chloroquine

Group 3: 5-(3,4,5-trimethoxybenzyl) pyrimidine -2,4-diamine (Trimethoprim)

Group 4: $\left[\mathrm{Co}(\mathrm{TMP})_{2} \mathrm{Cl}_{2}\right]$ 
Group 5: $\left[\mathrm{Cd}(\mathrm{TMP})_{2} \mathrm{Br}_{2}\right]$

The mice in each group were marked for easy identification. The mice received 0.2 $\mathrm{ml}$ of $1 \times 10^{6}$ parasitized erythrocyctes suspended in buffered physiological saline (pH 7.4) inoculated intravenously. The mice were left for 4 days, their level of parasitaemias were monitored daily by counting parasites in blood smear, fixed with $70 \%$ methanol and giemsa stained. The slide were then rinsed and allowed to dry. The slides were viewed under the microscope with magnification of 100. The level of parasitaemia was then determined by counting the number of infected erythrocytes $/ 1000$ erythrocyctes on tail blood smears stained with giemsa. $1 \mathrm{ppm}$ solution of each of the ligands and complexes was prepared. $0.4 \mathrm{ml}$ of each of the solution was injected daily into the mice in each group from day 0 to day 3 of infection. Levels of parasitaemia were determined on day 4. Only physiological saline solution was given to the control animals. The results were expressed as the percentage of infected cells or inhibition of parasitaemia calculated from the following equation:

$\%$ inhibition $=100-\frac{\text { EIPTC }}{\text { EIPTNC }}$

where, EIPTC = Estimated no of infected parasitaemia treated with compounds;

EIPTNC = Estimated no of infected parasitaemia treated with no compounds.

\section{Toxicological study}

Experimental animal and drug

A total of 30 male albino rats of average body weight $150 \mathrm{~g}$ were obtained from the Department of Biochemistry, University of Ilorin, Nigeria. The rats were fed for 2 weeks prior to usage. The rats were divided into 5 groups ( 6 rats each). Animals in Group A as the control and received DMSO, whereas group B were respectively administered with 5-(3,4,5-trimethoxybenzyl) pyrimidine-2,4-diamine (Trimethoprim) while groups $\mathrm{C}$ and $\mathrm{D}$ were administered accordingly with $\quad\left[\mathrm{Co}(\mathrm{TMP})_{2} \mathrm{Cl}_{2}\right]$, $\left[\mathrm{Cd}(\mathrm{TMP})_{2} \mathrm{Br}_{2}\right]$. The drug solution $(1 \mathrm{ml})$ prepared with DMSO were administered orally to the rats two times daily for five days at dosage level of $0.122 \mathrm{mg} / 150 \mathrm{~g}$. The control was given only DMSO.

\section{Preparation of serum and tissue homogenates}

The rats were sacrificed 24 hours after the last day of administration of drugs by anaesthetizing them in a glass jar containing cotton wool soaked in chloroform. The blood was collected into clean labelled sample bottles and allowed to coagulate. They were then centrifuged and the serum pipetted out for analysis. The homogenates of the liver, kidney, heart were prepared in ice cold 0.25 $\mathrm{M}$ sucrose solution to give a final volume of five times the original tissue weight $(1.55 \%$ w:v). The homogenates were kept in well labelled container and stored in the freezer before being used for analysis. The activities of alkaline phosphatase concentration in the serum and homogenates (liver, kidney and heart) were estimated using literature procedures (Bassey et al., 1946; Wright and Plummer, 1974 ; Gornall et al., 1949).

\section{RESULTS AND DISCUSSION}

Cadmium(II) and Cobalt(II) complexes of 5-(3,4,5-trimethoxybenzyl) pyrimidine-2,4diamine were isolated and characterized. The complexes were characterized by elemental analysis, UV-visible, Magnetic moment, IR spectroscopy. Cadmium(II) 5-(3,4,5trimethoxybenzyl) pyrimidine-2,4-diamine was further characterized by ${ }^{1} \mathrm{H}-\mathrm{NMR}$ and ${ }^{13}$ Carbon NMR. The analytical data of the complexes are summarized in Table 1. All the complexes were found to be non-electrolytes since they possess very low molar conductance values $\left(3.0-5.0 \Omega^{-1} \mathrm{~cm}^{2} \mathrm{~mol}^{-1}\right)$. The melting points and colours of the complexes were quite distinct from that of the corresponding ligand which is a confirmation of the formation of the complexes. The sharpness of the melting points is an indication of the purity of the compounds. The complexes are crystalline, very stable under 
atmospheric condition and of moderate yield. Elemental analysis and Job's method for stoichiometric determination of the complexes indicate a 1:2 mole ratio with respect to the metal and ligand respectively. The proposed general equation for the reaction is

$\mathrm{MX}_{2} \cdot \mathrm{nH}_{2} \mathrm{O}+2 \mathrm{~L} \longrightarrow \mathrm{ML}_{2} \mathrm{X}_{2}+\mathrm{nH}_{2} \mathrm{O}$ where $\mathrm{X}=$ Halide, $\mathrm{M}=$ Metal ion and $\mathrm{L}=$ Trimethoprim ligand.

The complexes were completely insoluble in water but soluble in acetone, chloroform and dimethylsulfoxide. 5-(3,4,5trimethoxybenzyl) pyrimidine-2,4-diamine possesses seven potential donor sites, two pyrimidinic $\mathrm{N}$ atoms, two $\mathrm{NH}_{2}$ group on the pyrimidine ring and three methoxyl groups. The pyrimidines provide potential binding sites for metal ions and any information on their coordinating properties is important for understanding the role of metal ions in biological systems (Demartzi-Kovala and Tsangaris , 1986).

But in all the two complexes, 5-( 3,4,5trimethoxybenzyl) pyrimidine-2,4-diamine acts as a monodentate ligand and binds through the pyrimidine $\mathrm{N}(1)$ with metal atoms in tetrahedral environment around the ligand. This mode of binding is in good agreement with previous work carried out on synthesis of Rhodium complex of trimethoprim (Zorroddu et al., 2000). The proposed structures of the complexes are shown in Figure 2.

\section{Infrared spectra of TMP and its complexes}

The IR spectra data of the 5-(3,4,5trimethoxybenzyl) pyrimidine-2,4-diamine and its complexes are presented in Table 2. The infrared spectra of the complexes and the ligand were compared, it was observed that absorption bands $\mathrm{V}_{\text {asy }}\left(\mathrm{NH}_{2}\right)$ and $\mathrm{V}_{\text {sy }}\left(\mathrm{NH}_{2}\right)$ modes of pyrimidine $-\mathrm{NH}_{2}$ group in the free ligand assigned to $3465-3354 \mathrm{~cm}^{-1}$ are not significantly shifted with respect to those of the complexes. The little shift may be due to hydrogen bonding as previously reported (Demartzi-Kovala and Tsangaris, 1986) not as a result of coordination.
The fact that the $\delta\left(\mathrm{NH}_{2}\right)\left(1633 \mathrm{~cm}^{-1}\right)$ in the ligand did not really shift to lower frequencies in the complexes suggests that the $\mathrm{NH}_{2}$ group is not involved in bonding to the metal ion (Bellany, 1957).

The band at $1595 \mathrm{~cm}^{-1}$ corresponding to $v(\mathrm{C}=\mathrm{N})$ exhibits a shift of $\left(\mathrm{ca} 6 \mathrm{~cm}^{-1}\right)$ upon complexation. This coordination of metal ion to the 5-(3,4,5-trimethoxybenzyl) pyrimidine2,4-diamine occurs through the pyrimidine $\mathrm{N}(1)$. A moderate weak sharp bands observed around $450 \mathrm{~cm}^{-1}$ and $690 \mathrm{~cm}^{-1}$ in the spectra of the complexes which are completely absent in the spectrum of the free ligand have been assigned to $v \mathrm{M}-\mathrm{N}$ and $v \mathrm{M}-\mathrm{Cl}$ bonds respectively (Moody, 1991).

\section{Electronic spectra of TMP and its complexes}

The electronic spectra in DMSO of the ligand and its complexes are shown in Table 3. The ligand gave one absorption band $\left(35971 \mathrm{~cm}^{-1}\right.$ ) $278 \mathrm{~nm}$ due to $\pi \rightarrow \pi^{*} / \mathrm{n} \rightarrow \pi^{*}$ (overlap of the two peaks) transitions within the benzene ring and $(\mathrm{C}=\mathrm{N})$ of the pyrimidine group. $\mathrm{Cd}(\mathrm{II})$ and $\mathrm{Co}(\mathrm{II}) \mathrm{TBP}$ complexes exhibit similar band around the same region but appear on the shorter wavelength side (hyperchromic shift) due to complexation.

As expected $\mathrm{Cd}(\mathrm{II})$ of trimethoprim do not have additional bands in the visible region ( $d-d$ transition). The visible region spectrum of $\mathrm{Co}$ (II) 5-(3,4,5-trimethoxybenzyl) pyrimidine-2,4-diamine complex indicates additional three bands which are attributed to metal-ligand charge $\left(24390 \mathrm{~cm}^{-1}\right) 410 \mathrm{~nm},{ }^{4} \mathrm{~A}_{2}$ $\rightarrow{ }^{4} \mathrm{~T}_{1}\left(22472 \mathrm{~cm}^{-1}\right) 445 \mathrm{~nm}$ and ${ }^{4} \mathrm{~A}_{2} \rightarrow{ }^{4} \mathrm{~T}_{2}$ $\left(16639 \mathrm{~cm}^{-1}\right) 601 \mathrm{~nm}$, respectively suggesting tetrahedral stereochemistry around the metal ion (Preth and Giuseppe, 1976).

Proton and carbon 13- NMR spectra of 5-
(3,4,5-trimethoxybenzyl) pyrimidine-2,4-
diamine and [Cd(TMP) $)_{2} \mathbf{B r}_{2}$ ] complex
${ }^{1} \mathrm{H}-\mathrm{NMR}$ and ${ }^{13} \mathrm{C}-\mathrm{NMR}$ spectra and
the assignments for trimethoprim and
$\left[\mathrm{Cd}(\mathrm{TMP})_{2} \mathrm{Br}_{2}\right]$ are shown in Table 4 and
Figures 3-6. The peak at $\delta 5.85$ ppm due to
protons of the two $\mathrm{NH}_{2}$ groups in 5-(3,4,5-


trimethoxybenzyl) pyrimidine-2,4-diamine ligand exhibited downfield shift to $6.40 \mathrm{ppm}$ in the $\left[\mathrm{Cd}(\mathrm{TMP})_{2} \mathrm{Br}_{2}\right]$. This is probably due to deshielding effect via intramolecular or intermolecular hydrogen bonding (DemartziKovala and Tsangaris, 1986).

The H-6 signal of pyrimidine proton is slightly shifted from $6.25 \mathrm{ppm}$ in the ligand to $6.90 \mathrm{ppm}$ in the complex due to the coordination of the pyrimidine $\mathrm{N}(1)$ atom to the metal ion.

The ${ }^{13} \mathrm{C}$ - NMR of the ligand and the cadmium complex showed that the signal of C-6 (at $156 \mathrm{ppm}$ ) in the ligand) is shifted to high field value (at $152.41 \mathrm{ppm}$ ) for cadmium complex. So also the coordination of the trimethoprim to the metal ion causes a deshielding of C-5 atom in pyrimidine ring (at $105.96 \mathrm{ppm}$ in the ligand to $107.40 \mathrm{ppm}$ ) in the cadmium complex. It can also be seen that some signals of carbon atom are slightly shifted as a consequence of the fact that the ligand is coordinated to cadmium(II) (Tella, 2008).

\section{Magnetic moment of the complexes}

The magnetic moment results of complexes are shown in Table 1. The magnetic moment of 0.7 B.M for $\mathrm{Cd}(\mathrm{II})$ complex confirm that the complex is diamagnetic.

The expected magnetic moment for tetrahedral structure of cobalt(II) complex is
4.4-4.8 B.M, but cobalt(II) TMP has a value of 4.1 B.M. The low value of the magnetic moment of the complex indicates that the complex is not purely tetrahedral geometry but probably a distorted tetrahedral (Bailar et al., 1975).

\section{Biological studies}

Table 5 presents alkaline phosphatase activities (ALP) in the kidney, liver and serum following administration of the parent drug and complexes. There was no increase in serum ALP activities in the parent drugs and derivatives when compared with the control, the observed increase in ALP activities in the liver and kidney suggests stimulation of the enzyme activities by the drugs and their metabolites which could be due to stress imposed on the tissues by the drugs (Akanji et al., 1993). Non-increment in serum ALP suggests that the integrity of the cell membranes of the various tissues (especially the liver and kidney) were not adversely affected. Therefore the complexes exhibited lower toxicity than the parent drugs. This finding is in agreement with previous work of (O. Neil et al., 1999; Zhou et al., 2000; Biot et al., 1999). The results of \% reduction in parasitaemia of the TMP, chloroquine, $\begin{array}{lllll}\mathrm{Co}(\mathrm{TMP})_{2} & \mathrm{Cl}_{2} & \text { and } \mathrm{Cd}(\mathrm{TMP})_{2} & \mathrm{Br}_{2} & \text { are }\end{array}$ presented in Table 6 .

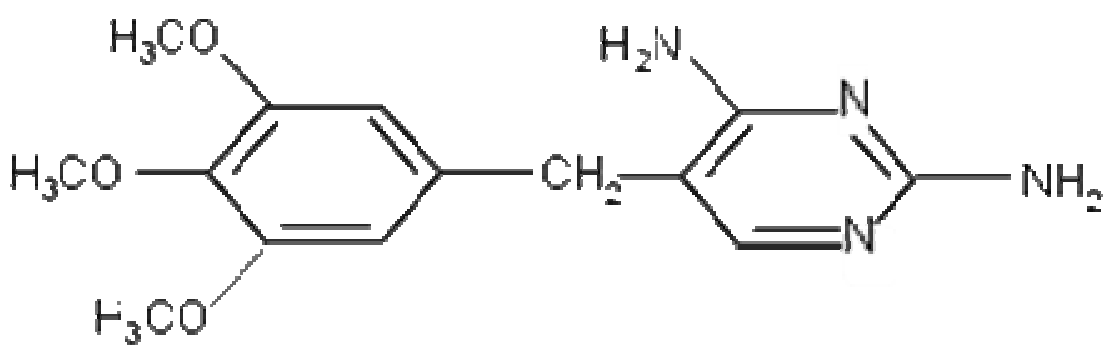

Figure 1: Molecular Structure of 5-(3,4,5-trimethoxybenzyl) pyrimidine-2,4- diamine (Trimethoprim). 


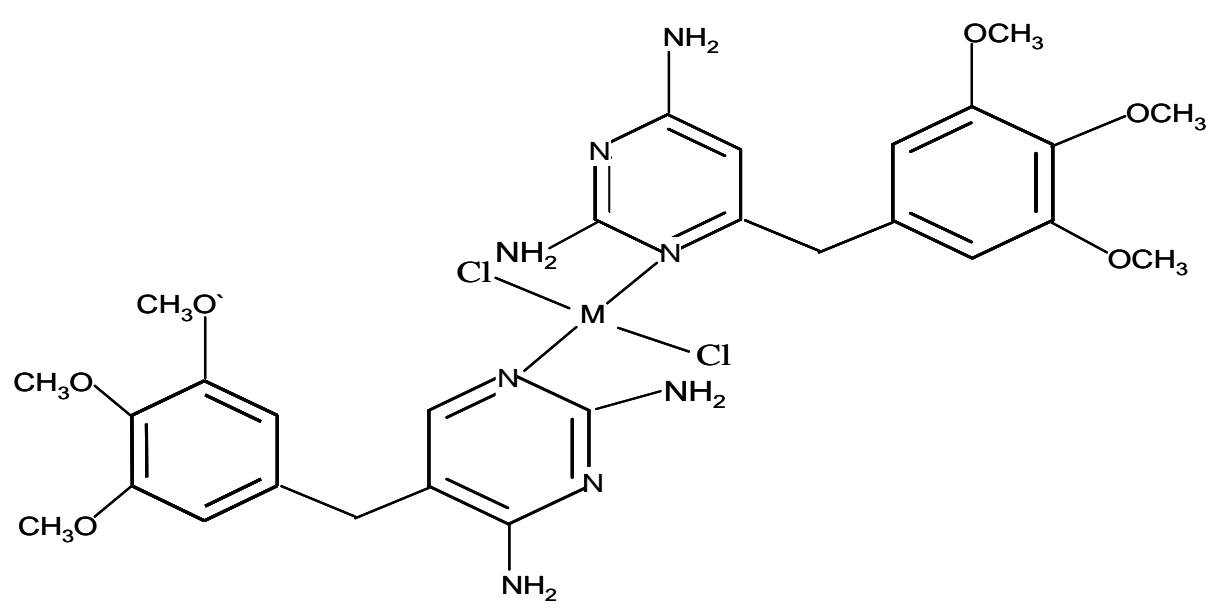

Figure 2: Proposed structure for metal(II) complex of 5-(3,4,5-trimethoxybenzyl) pyrimidine2,4-diamine $\mathrm{M}=\mathrm{Co}(\mathrm{II}), \mathrm{Cd}(\mathrm{II})$.

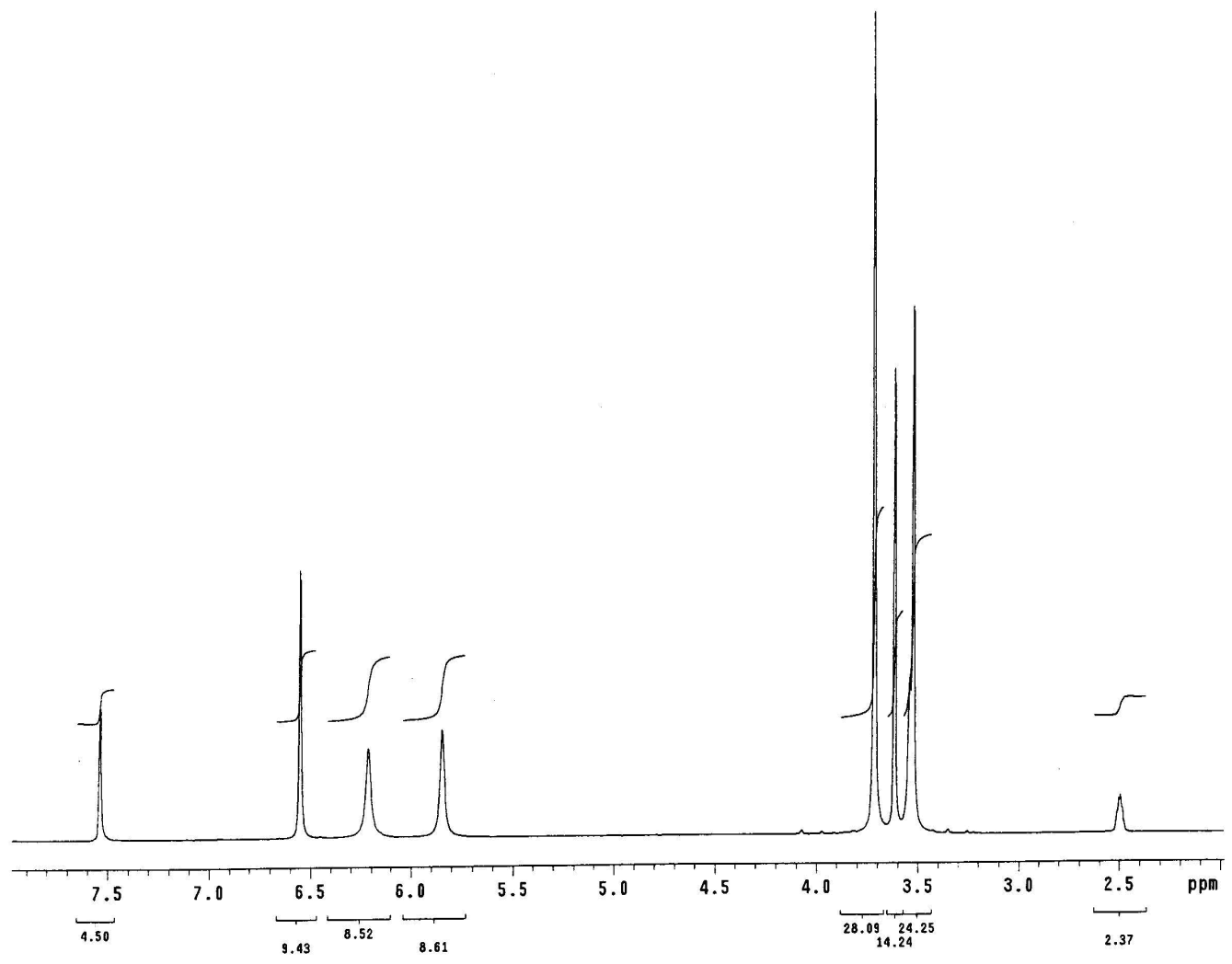

Figure 3: ${ }^{1} \mathrm{HNMR}$ spectra of TMP. 
A. C. TELLA et al. /Int. J. Biol. Chem. Sci. 4(6): 2181-2191, 2010

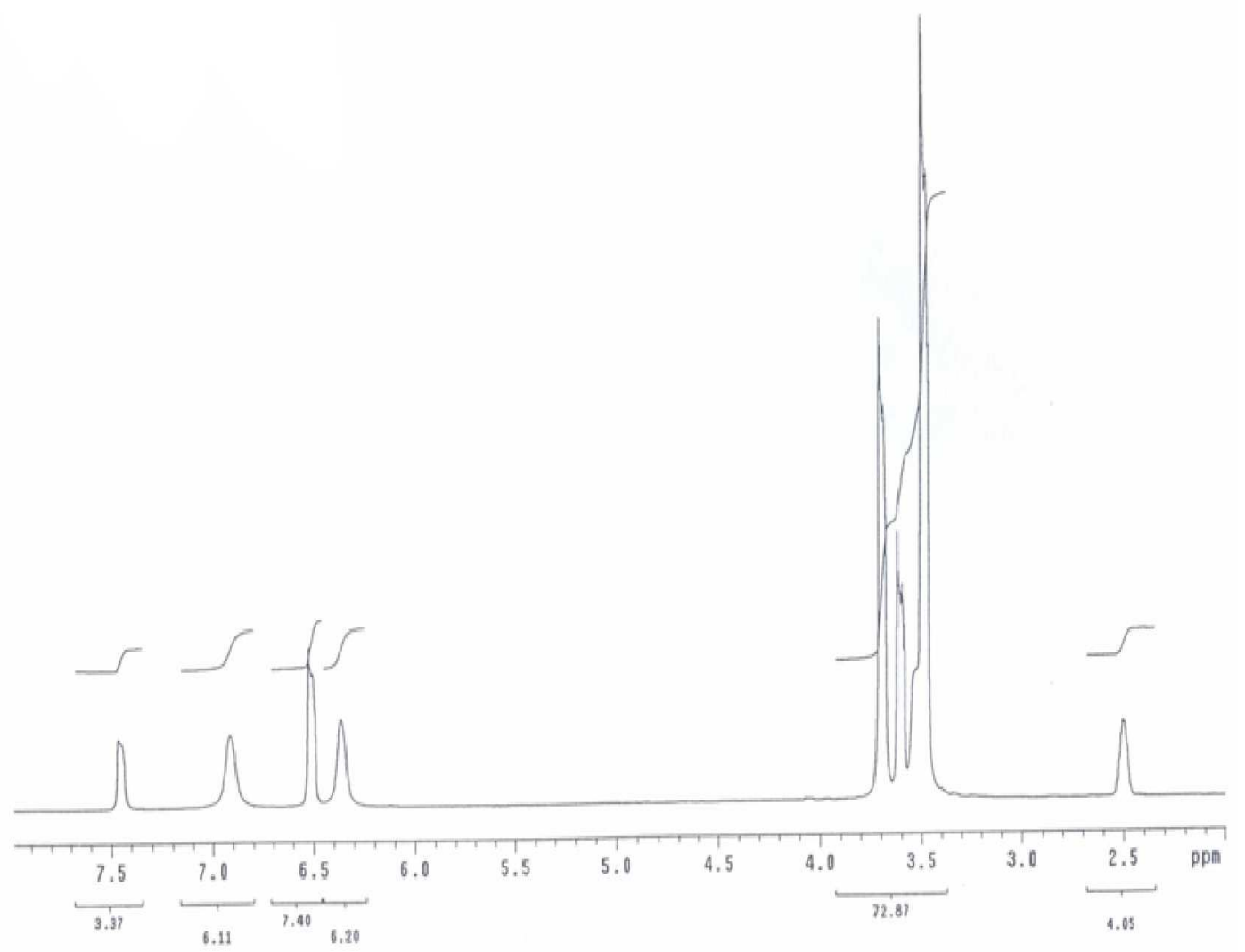

Figure 4: ${ }^{1} \mathrm{HNMR}$ spectra of $\left[\mathrm{Cd}(\mathrm{TMP})_{2} \mathrm{Br}{ }_{2}\right]$.

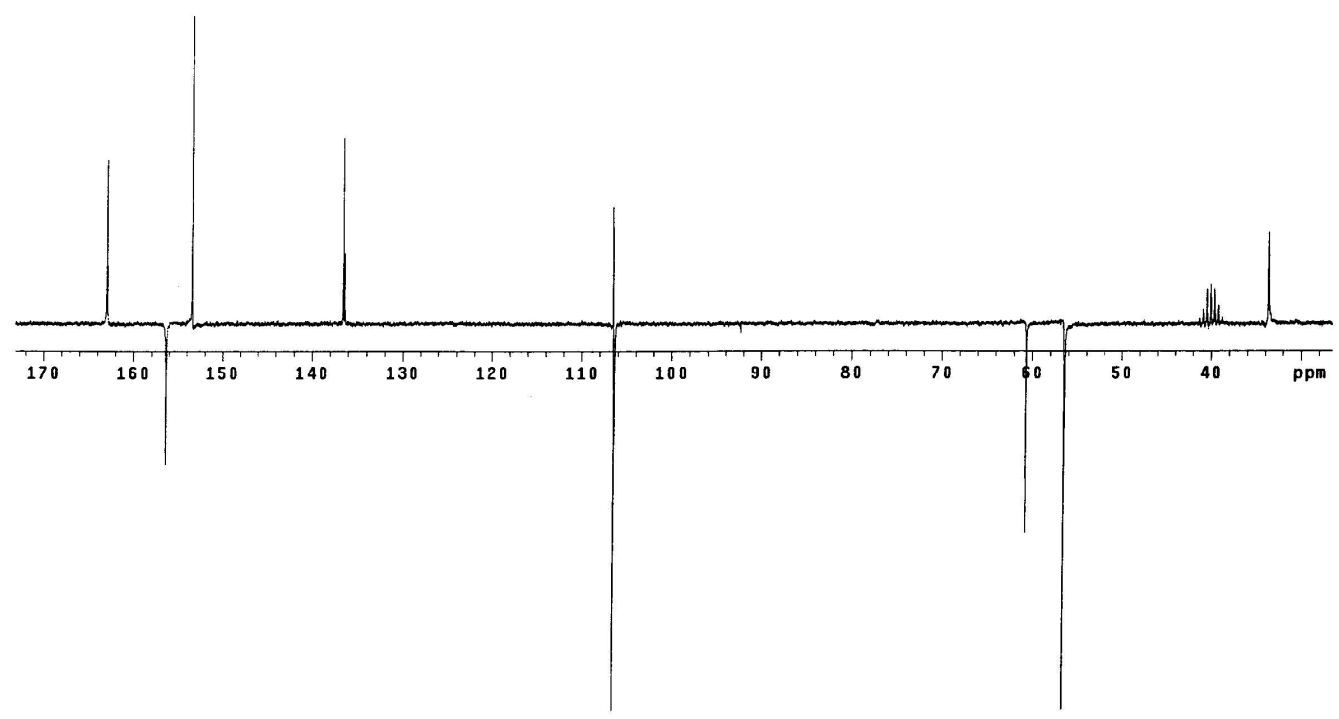

Figure 5: ${ }^{13}$ CNMR spectra of TMP. 


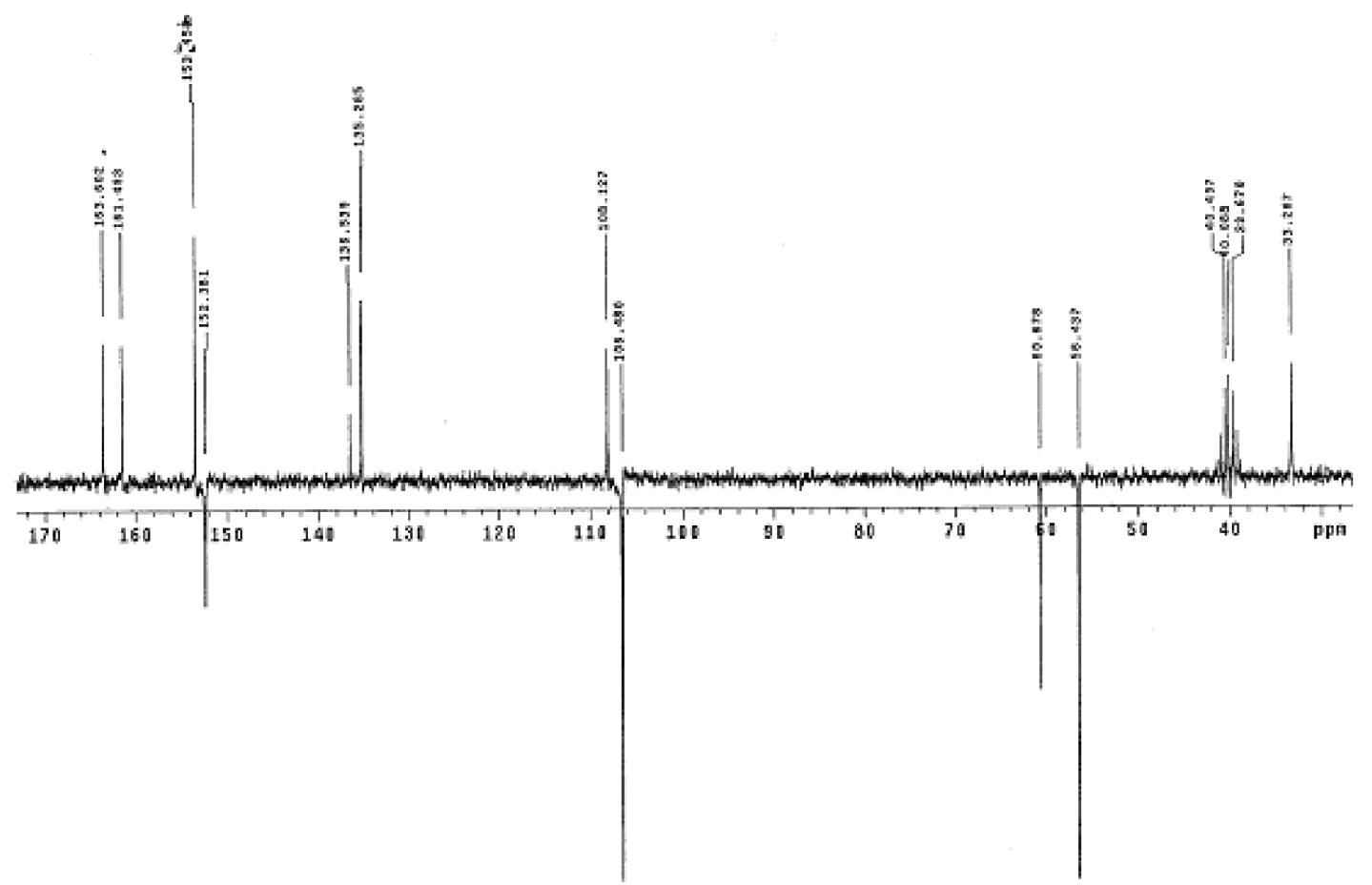

Figure 6: ${ }^{13}$ Carbon NMR spectra of $\left[\mathrm{Cd}(\mathrm{TMP})_{2} \mathrm{Br}_{2}\right]$.

Table 1: Analytical data for TMP and its complexes.

\begin{tabular}{|c|c|c|c|c|c|c|c|c|c|}
\hline \multirow[t]{2}{*}{ Complexes } & \multirow[t]{2}{*}{ Colour } & \multirow{2}{*}{$\begin{array}{c}\text { Molar } \\
\text { mass }\end{array}$} & \multirow[t]{2}{*}{ M.pt } & \multicolumn{4}{|c|}{ Experimental (calculated) } & \multirow{2}{*}{$\begin{array}{l}\text { Conductivity } \\
\Omega^{1} \mathrm{~cm}^{-1} \mathrm{~mol}^{-1}\end{array}$} & \multirow{2}{*}{$\begin{array}{c}\text { Magnetic } \\
\text { moment } \\
(B M)\end{array}$} \\
\hline & & & & $\% \mathrm{C}$ & $\% \mathrm{H}$ & $\% \mathrm{~N}$ & $\% \mathrm{M}$ & & \\
\hline$\left[\mathrm{Co}(\mathrm{TMP})_{2} \mathrm{Cl}_{2}\right]$ & Blue & 719.57 & $268^{\circ} \mathrm{C}$ & $\begin{array}{c}47.45 \\
(47.28)\end{array}$ & $\begin{array}{c}4.95 \\
(5.07)\end{array}$ & $\begin{array}{c}15.92 \\
(15.76)\end{array}$ & $\begin{array}{c}8.27 \\
(8.29)\end{array}$ & 3.0 & 4.1 \\
\hline$\left[\mathrm{Cd}(\mathrm{TMP})_{2} \mathrm{Br}_{2}\right]$ & White & 852.84 & $235^{\circ} \mathrm{C}$ & $\begin{array}{c}39.51 \\
(39.40)\end{array}$ & $\begin{array}{c}4.15 \\
(4.22)\end{array}$ & $\begin{array}{c}13.21 \\
(13.15)\end{array}$ & $\begin{array}{c}13.05 \\
(13.10)\end{array}$ & 4.6 & 0.7 \\
\hline
\end{tabular}

Table 2: Selected IR data $\left(\mathrm{cm}^{-1}\right)$ for TMP and its complexes.

\begin{tabular}{|c|c|c|c|c|c|c|c|}
\hline & $\mathrm{vNH}_{2}($ asy \& sym $)$ & $v N-H$ & $v \mathrm{CH}_{2}$ & $\delta \mathrm{NH}_{2}$ & $v C=N$ & $v M-N$ & $v M-C l$ \\
\hline TMP & $\begin{array}{l}3465 \mathrm{vs} \\
3354 \mathrm{vs}\end{array}$ & $3123 \mathrm{~s}$ & $2940 \mathrm{~m}$ & $1633 \mathrm{~s}$ & $1595 \mathrm{~m}$ & - & - \\
\hline $\mathrm{Co}(\mathrm{TMP})_{2} \mathrm{Cl}_{2}$ & $\begin{array}{l}3465 \mathrm{vs} \\
3336 \mathrm{vs}\end{array}$ & $3184 \mathrm{~m}$ & $2936 \mathrm{~m}$ & $1634 \mathrm{~s}$ & $\begin{array}{c}1664 \mathrm{~m} \\
1590 \mathrm{~s}\end{array}$ & $480 \mathrm{~m}$ & $620 \mathrm{~m}$ \\
\hline $\mathrm{Cd}(\mathrm{TMP})_{2} \mathrm{Br}_{2}$ & $\begin{array}{l}3429 \mathrm{~s} \\
3341 \mathrm{~s}\end{array}$ & $3227 \mathrm{~s}$ & $2938 \mathrm{~s}$ & $1631 \mathrm{~s}$ & 1590 & $457 \mathrm{~m}$ & $683 w$ \\
\hline
\end{tabular}

$\mathrm{S}=$ strong, vs= very strong, $\mathrm{m}=$ medium, $\mathrm{w}=$ weak, $\mathrm{vw}=$ very weak 
Table 3: Electronic spectra for TMP and its complexes.

\begin{tabular}{lccc}
\hline Ligand /Complexes & Wavelength $(\mathbf{n m})$ & Energies $\mathbf{c m}^{-1}$ & Assignment \\
\hline TMP & 278 & 35971 & $\pi \rightarrow \pi^{*} / \mathrm{n} \rightarrow \pi^{*}$ \\
{$\left[\mathrm{Cd}(\mathrm{TMP})_{2} \mathrm{Br}_{2}\right]$} & 275 & 36364 & $\pi \rightarrow \pi^{*} / \mathrm{n} \rightarrow \pi^{*}$ \\
{$\left[\mathrm{Co}(\mathrm{TMP})_{2} \mathrm{Cl}_{2}\right]$} & 410 & 24390 & Metal - ligand charge \\
& 445 & 22472 & ${ }^{4} \mathrm{~A}_{2} \rightarrow{ }^{4} \mathrm{~T}_{1}$ \\
& 601 & 16639 & ${ }^{4} \mathrm{~A}_{2} \rightarrow{ }^{4} \mathrm{~T}_{2}$ \\
\hline
\end{tabular}

Table 4: Proton and carbon NMR spectra of TMP and [Cd(TMP $\left.)_{2} \mathrm{Br}_{2}\right]$ complex.

\begin{tabular}{lcccc}
\hline Assignments & ${ }^{1} \mathbf{H}($ Trim) & ${ }^{\mathbf{1}} \mathbf{H}$ (Complex) & ${ }^{{ }^{13}} \mathbf{C}($ Trim) & ${ }^{\mathbf{1 3}} \mathbf{C}(\mathbf{C o m p l e x})$ \\
\hline$(2 \mathrm{H}), \mathrm{NH}_{2}$ & 5.85 & 6.40 & - & - \\
$6), \mathrm{H}(6)$ & 6.25 & 6.90 & 156 & 152.41 \\
$\mathrm{H}(7)$ & 6.5 & 6.5 & - & - \\
$\mathrm{H}\left(6^{\prime}\right) / \mathrm{H}\left(2^{\prime}\right)$ & 7.5 & 7.5 & - & - \\
$\mathrm{C}(5)$ & - & - & 105.9 & 107.40 \\
\hline
\end{tabular}

Table 5: Effects of administration of TMP and its complexes on alkaline phosphatase activities of rat liver, kidney and serum.

\begin{tabular}{lccc}
\hline Ligand/Complexes & Kidney (IU/L) & Liver (IU/L) & Serum (IU/L) \\
\hline Control & $66.20 \pm 5.11$ & $20.08 \pm 1.90$ & $10.8 \pm 0.98$ \\
TMP & $71.40 \pm 5.09$ & $25.56 \pm 2.15$ & $10.00 \pm 0.90$ \\
$\mathrm{Cd}(\mathrm{TMP})_{2} \mathrm{Br}_{2}$ & $76.40 \pm 6.85$ & $30.42 \pm 2.73$ & $8.77 \pm 0.57$ \\
$\mathrm{Co}(\mathrm{TMP})_{2} \mathrm{Cl}_{2}$ & $73.45 \pm 5.67$ & $26.56 \pm 5.89$ & $9.43 \pm 0.88$ \\
\hline
\end{tabular}

Values are mean of 5 determinations \pm SD. Enzyme activities are expressed in U/I/min/mg protein. .

Note Student's t-test and Duncan's multiple range test (Duncan, 1955) were carried out on the results using the computer software package SPSS version 12

Table 6 : Percentage parasitaemia of chloroquine, TMP and its metal complexes.

\begin{tabular}{lcccc}
\hline No & $\begin{array}{c}\text { \%Average } \\
\text { parasitaemia } \\
\text { before administration }\end{array}$ & $\begin{array}{c}\text { \%Average } \\
\text { parasitaemia after } \\
\text { administration }\end{array}$ & $\begin{array}{c}\text { \% Reduction } \\
\text { in parasitaemia }\end{array}$ \\
\hline Chloroquine & 1 & 40 & 13 & 68 \\
TMP & 2 & 60 & 24 & 60 \\
{$\left[\mathrm{Co}(\mathrm{TMP})_{2} \mathrm{Cl}_{2}\right]$} & 3 & 38 & 21 & 45 \\
{$\left[\mathrm{Cd}(\mathrm{TMP})_{2} \mathrm{Br}_{2}\right]$} & 4 & 36 & 19 & 47 \\
\hline
\end{tabular}

The complexes were screened for their potencies against a causative organism of malarial diseases. The antipasmodial activity was evaluated using mice infected with Plasmodium berghei. The complexes exhibited lower antimalarial activities than TMP and chloroquine. This indicates that coordination of the metal to TMP reduces its antimalarial activities. The $\%$ parasitaemia reduction for [Co(TMP $\left.)_{2} \mathrm{Cl}_{2}\right],\left[\mathrm{Cd}(\mathrm{TMP})_{2} \mathrm{Br}_{2}\right]$, TMP and chloroquine are 45\%, 47\%, 60\% and $68 \%$ respectively. This is in agreement with the results of our previous work on Copper Complexes of 4,4-diaminodiphenylsulphone (Tella and Obaleye, 2009). 


\section{Conclusion}

Two complexes of $\left[\mathrm{Co}(\mathrm{TMP})_{2} \mathrm{Cl}_{2}\right]$, $\left[\mathrm{Cd}(\mathrm{TMP})_{2} \mathrm{Br}_{2}\right]$ were synthesized and isolated. They were characterized using elemental analysis, IR, UV, magnetic moment, ${ }^{1} \mathrm{HNMR}$ and ${ }^{13} \mathrm{CNMR}$ spectroscopies. The complex is a 4-coordinate complex containing two molecules of 3,4,5Trimethoxypyrimidine and two chloride ions. The two complexes have distorted tetrahedral geometry. 5-(3,4,5-trimethoxybenzyl) pyrimidine-2,4-diamine acts as a monodentate ligand and binds through the pyrimidine $\mathrm{N}(1)$. The complexes were found to be non-toxic as compared to parent drug. The antiparasitic studies using Plasmodium berghei as a test organism showed that the complexes exhibit lower activity than chloroquine and ligand. This indicates that the complexes were not effective than the parent drug.

\section{ACKNOWLEDGEMENTS}

We are grateful for financial support from the Science and Technology Education Post Basic Project (Step B) and the University of Ilorin.

\section{REFERENCES}

Akanji MA, Olagoke OA, Oloyede OB. 1993. Effects of chronic consumption of metasulphite on the activity of the rat kidney cellular system. Toxicol., 81: 173179.

Anacona JR, Goli, CC. 2005. Synthesis and antibacterial activity of cefoxitin metal complexes. Transit. Met. Chem., 30: 605-609.

Bailar JC, Emeleus HJ, Nyholm R, TrotmanDickenson AF. 1975. Comprehensive Inorganic Chemistry (3rd edn). Pergamon Press: New York; 1048-1153.

Bassey OA, Lowry OH, Brock MA.1946. A method for the rapid determination of Alkaline Phosphatase with 5 cubic millimeter of Serum. J. Biol. Chem., 164: $321-329$.
Bellany LJ. 1957. The Infrared Spectra of Complex Molecules. John Wiley: New York; 249.

Biot C, Delhaes L, Abessolo H .1999. Novel Metallocenic compounds as antimalarial agents: Study of the position of ferrocene in chloroquine. J. Org. chem., 589(1): 5765.

Demartzi-Kovala D, Tsangaris JM. 1986. Complexes of 2,4 - Diamine - 5 (3,4,5 Ttrimethoxybenzylpyrimidine (Trimethoprim) with palladium(II). Inorg. Chim. Acta , 125: L31-L33.

Gornall AC, Bardawill CJ, David MM. 1949. Determination of serum protein by means of biuret reaction. J. Biol. Chem., 177: 751-756.

Moody B. 1991. Comparative Inorganic Chemistry (3rd edn). Thomson Litho Ltd: Great Britain; 464.

Navarro M, Perez J, Sanchez - Delgado R. 1997. Metallic derivatives of chloroquine with antimalarial. J. Med. Chem., 40: 1937.

Neal MJ. 1987. Medical Pharmacology at a Glance (2nd edn). Blackwell scientific Publications: London; 76-77.

O. Neil PM, Harrison AC, Storr RC, Hawler SR, Ward SA, Park PK. 1994. The effect of fluorine substitution on the activity of amodiaquine. J. Med . Chem., 37: 1362-1370.

Obaleye JA, Caira MR, Tella AC. 2008. Crystal structure of dichlorobis $(\mathrm{N}-\{4$ (2-Pyrimidinyl- $\mathrm{kN}$ - aminosulfonylacetamide)Copper(II). Anal. Sci., 24: x 63.

Obaleye JA, Caira MR, Tella AC. 2009. Synthesis, characterization and crystal structures of the tetrachlorocuprate and tetrabromocadmate salts of the antimalarial mefloquine. Struct. Chem., 20: 859-868.

Obaleye JA, Caira MR, Tella AC. 2007. Synthesis, characterization and crystal structure of a polymeric zinc(II) complex containing the antimalarial quinine as ligand. J. Chem. Crystallogr., 37: 707712. 
Orvig C, Abrahams MJ. 1999. Medicinal lnorganic Chemistry. Chem. Rev., 99(9): 2201-2203.

Preth C, Giuseppe T. 1976. Preparation, magnetic and spectral studies of some transition metal complexes of Benzoxazole -2- thione. J. Inorg. Nucl. Chem., 38: 1125-1129.

Rang HB, Dale MM, Rither JM. 1999. Pharmacology (4th edn). Churchill Livingstone; 725-731.

Regtop HL. 2000. Synthesis and characterization of anti-inflammatory dinuclear and mononuclear. Zinc indomethacin complexes. Crystal structures $\left.\left(\mathrm{Zn}_{2} \text { (Indomethacin }\right)_{4}(\mathrm{~L})_{2}\right]$ and (Zn (Indomethacin $)_{2}(\mathrm{~L})_{2}$ ]. Inorg. Chem., 39: 3742-3748.

Sanchez - delgado RA, Navarro M, Perez H, Urbina JA. .1996. Toward a Novel-based chemotherapy against tropical diseases: Synthesis and antimalarial activity invitro and in-vivo of new ruthenium and rhodium - chloroquine complexes. $J$. Med. Chem., 39: 1095-1099.

Sanchez-Delgado RA, Lazardi K, Rincom L, Urbina JA, Hubert AJ, Noels AW. 1993. Toward a novel metal Chemotherapy against tropical diseases 1 . Enhancement of the efficacy of clotrimazole against Trypanosome cruzi by complexation to ruthenium in $\mathrm{RuCl}_{2}$ (Clotrimazole) 2. J. Med. Chem., 36(14): 2041-2043.

Sayles PC, Wassom DL. 1988. Immunoregulation in Murine Malarial Susceptibility of inbred mice of infection with Plasmodium yoeli depends on dynamic interplay of host and parasite genes. J. Immunol., 76: 241-248.

Sorenson JRJ. 1976. Copper chelates as possible active forms of the antiarthritic agents. J. Med. Chem., 19: 135-148.
Zorroddu MA, Naldini L, Dermatin F, Masciocchi N. 1987. Metal complexes of 2,4-Diamino-5-( $3^{1}, 4^{1}, 5^{1}$-trimethoxybenzyl) pyrimidine (Trimethoprim) and 2,4 diamino - 5- (P-chlorophenyl) - 6- ethyl pyrimidine (pyrimethamine). Part III Synthesis and X-ray structures of $\left[\mathrm{Rh}_{2}\right.$

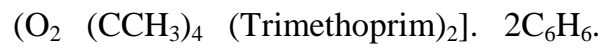
$\mathrm{CH}_{3} \mathrm{OH}$ and $\left(\mathrm{Rh}_{2} \quad\left(\mathrm{O}_{2} \mathrm{CCH}_{3}\right)_{4}\right.$ (pyrimethamine $)_{2}$ ]. Inorg. Chim. Acta, 128: $79-83$.

Tella AC, Obaleye JA. 2010. Metal complexes as antibacterial agents: synthesis, characterizations and antibacterial activity of some $3 \mathrm{~d}$ metal complexes of sulphadimidine. Orbital Elec. J. Chem. Campo Grande, 2(1): 1126.

Tella AC, Obaleye JA. 2010 Synthesis of some $3 \mathrm{~d}$ metal complexes of quinine and their toxicological studies. J. Nepal Chem. Soc., 25: 19-28.

Tella AC, Obaleye JA. 2009. Copper(II) Complexes of 4,4-diaminodiphenylsulphone: synthesis, characterization and biological studies. E-J. Chem., 6(S1): S311-S323.

Tella AC. 2008. Synthesis, structural and biological studies of quinolinemethanol, sulphone, pyrimidine and sulpha metal complexes. PhD Thesis, University of Ilorin , Nigeria, pp. 145-146.

Wright PJ, Plummer DJ. 1974. The use of urinary enzymes measurement to detect renal damage caused by nephritic compounds. Biochem. Pharmacol., 23: 65-75.

Zhou Q, Hambley TW, Kennedy BJ, Ley PA, Turner P, Warwick B, Biffin JR Regtop HL. 2000. Synthesis and characterization of anti-inflammatory dinuclear and mononuclear. Zinc indomethacin complexes. Crystal structures $\left.\left(\mathrm{Zn}_{2} \text { (Indomethacin }\right)_{4}(\mathrm{~L})_{2}\right]$ and (Zn (Indomethacin $)_{2}(\mathrm{~L})_{2}$ ] . Inorg. Chem., 39: 3742-3748. 